\title{
PELATIHAN DAN EDUKASI POLA HIDUP SEHAT DALAM PENCEGAHAN HIPERTENSI WARGA DI SEKITAR JAKARTA BARAT MELALUI SENAM DAN PENGUKURAN TEKANAN DARAH
}

\author{
Alexander Halim Santoso ${ }^{1}$, Novendy ${ }^{2}$, dan Susy Olivia Lontoh ${ }^{3}$ \\ ${ }^{1}$ Bagian Ilmu Gizi, Fakultas Kedokteran, Universitas Tarumanagara Jakarta \\ Email: alexanders@fk.untar.ac.id \\ ${ }^{2}$ Bagian Ilmu Kesehatan Masyarakat, Fakultas Kedokteran, Universitas Tarumanagara \\ Email: novendy@fk.untar.ac.id \\ ${ }^{3}$ Bagian Ilmu faal, Fakultas Kedokteran, Universitas Tarumanagara Jakarta \\ Email: susyo@fk.untar.ac.id
}

\begin{abstract}
Hypertension can cause serious health condition such as heart attack, kidney failure and stroke. A person's blood pressure is considered hypertensive if it is $140 / 90 \mathrm{mmHg}$, and 139/89 $\mathrm{mmHg}$ is called pre-hypertension. An increase of $20 \mathrm{mmHg}$ systolic blood pressure or $10 \mathrm{mmHg}$ diastolic blood pressure can increase the risk of death from ischemic heart disease and stroke. Living a healthy lifestyle for at least 4-6 months has been shown to lower blood pressure and can lower the risk of cardiovascular problems. The recommended healthy lifestyles include weight loss, reducing salt intake, exercise, reducing alcohol consumption, and quitting smoking. Lifestyle is an important risk factor for hypertension in young adult. The team leader visited the cadres at the village office to convey the objectives of the service activities. The distribution of invitations was carried out by cadres from Kelurahan Tomang and Kelurahan Grogol. Participants registered and then filled out a questionnaire. Then they were directed to check blood pressure. After that, participants filled out the questionnaire and watch the exercise demo. This service activity involves Medical students of the Tarumanagara University. The number of residents who participated in this event were in total of 181 residents from Tomang and Grogol, West Jakarta. The results of blood pressure measurements, found that $88.4 \%$ of residents had blood pressure classified as normal. The mean systolic blood pressure was $130.82 \mathrm{mmHg}$, and the diastolic blood pressure $77.69 \mathrm{mmHg}$. Continuous efforts are needed in the form of counseling to continue to increase hypertension awareness.
\end{abstract}

Keywords: education, healthy living, hypertension, gymnastic, blood pressure

\begin{abstract}
ABSTRAK
Hipertensi adalah faktor penyebab timbulnya penyakit berat seperti serangan jantung, gagal ginjal dan stoke. Tekanan darah orang dikatakan hipertensi apabila 140/90 mmHg dan 139/89 mmHg disebut prahipertensi. Peningkatan $20 \mathrm{mmHg}$ tekanan darah sistolik atau $10 \mathrm{mmHg}$ tekanan darah diastolik dapat meningkatkan risiko kematian akibat penyakit jantung iskemik dan stroke. Menjalankan pola hidup sehat setidaknya selama 4-6 bulan terbukti dapat menurunkan tekanan darah dan secara umum dapat menurunkan risiko permasalahan kardiovaskular. Beberapa pola hidup sehat yang dianjurkan di antaranya penurunan berat badan, mengurangi asupan garam, olahraga, mengurangi konsumsi alkohol, dan berhenti merokok. Gaya hidup merupakan faktor risiko penting timbulnya hipertensi pada seseorang di usia dewasa muda. Pada hari yang telah disepakati, ketua tim melakukan kunjungan kepada para kader di kantor kelurahan untuk menyampaikan tujuan kegiatan pengabdian. Selanjutnya, penyebaran undangan dilakukan oleh para kader dari Kelurahan Tomang dan Kelurahan Grogol. Pada hari pelaksanaan, peserta melakukan registrasi dan kemudian mengisi kuesioner. Selanjutnya peserta diarahkan untuk pemeriksaan tekanan darah. Setelah pengukuran tekanan darah, peserta dikumpulkan kembali untuk melanjutkan pengisian kuesioner dan melihat demo senam melalui video. Kegiatan pengabdian ini melibatkan mahasiswa Fakultas Kedokteran Universitas Tarumanagara. Jumlah warga yang harid sebanyak 181 warga dari Kelurahan Tomang dan Grogol Jakarta Barat, Hasil pengukuran tekanan darah, didapatkan 88,4\% warga tekanan darahnya tergolong normal. Rata-rata tekanan darah sistolik adalah 130,82 mmHg, dan tekanan darah diastolik $77.69 \mathrm{mmHg}$. Diperlukan upaya berkelanjutan dalam bentuk penyuluhan untuk tetap meningkatkan kewaspadaan dan pengetahun masyarakat akan Hipertensi.
\end{abstract}

Kata kunci: edukasi, pola hidup sehat, hipertensi, senam, tekanan darah 


\section{PENDAHULUAN}

Penyakit tidak menular (PTM) merupakan masalah kesehatan utama di negara-negara maju. Berdasarkan data WHO (2013), pada tahun 2008 angka kematian Penyakit Tidak Menular (PTM) di Indonesia mencapai 647 per 100.000 penduduk.(WHO, 2013) Menurut Kemenkes RI (2012), pada tahun 2008 di Indonesia terdapat 582.300 laki-laki dan 481.700 perempuan meninggal karena PTM.(Badan Penelitian dan Pengembangan Kesehatan Kementerian Kesehatan RI, 2013)

Penyakit jantung dan pembuluh darah (kardiovaskuler) merupakan masalah kesehatan utama di negara maju maupun negara berkembang. Hipertensi menjadi penyebab kematian nomor satu di dunia setiap tahunnya. Hipertensi merupakan salah satu penyakit kardiovaskular yang paling umum dan paling banyak disandang masyarakat. Hipertensi merupakan penyakit tidak menular, penyakit degeneratif ini banyak terjadi dan mempunyai tingkat mortalitas yang cukup tinggi serta mempengaruhi kualitas hidup dan produktifitas seseorang. Hipertensi sering diberi gelar The Sillent Killer karena penyakit ini merupakan pembunuh tersembunyi.(WHO, 2013) Penyakit tekanan darah atau hipertensi telah membunuh 9,4 juta warga di dunia setiap tahunnya. World Health Organization (WHO) memperkirakan jumlah penderita hipertensi akan terus meningkat seiring dengan jumlah penduduk yang meningkat. Pada tahun 2025 mendatang, diproyeksikan sekitar 29\% warga di dunia terkena hipertensi (WHO, 2013).

Hipertensi adalah peningkatan tekanan darah sistolik lebih dari $140 \mathrm{mmHg}$ dan tekanan darah diastolik lebih dari $90 \mathrm{mmHg}$ pada dua kali pengukuran dengan selang waktu lima menit dalam keadaan cukup istirahat/tenang. Peningkatan tekanan darah dengan jangka waktu yang lama dapat menimbulkan kerusakan pada ginjal, jantung dan otak apabila tidak dilakukan pengobatan secara dini.(Pusat Data dan Informasi Kementerian Kesehatan Republik Indonesia, 1997)

Data World Health Organization (WHO) tahun 2015 menunjukkan sekitar 1,13 Miliar orang di dunia menyandang hipertensi, artinya 1 dari 3 orang di dunia terdiagnosis hipertensi. Jumlah penyandang hipertensi terus meningkat setiap tahunnya, diperkirakan pada tahun 2025 akan ada 1,5 Miliar orang yang terkena hipertensi, dan diperkirakan setiap tahunnya 9,4 juta orang meninggal akibat hipertensi dan komplikasinya.("Hypertension," n.d.)

Menurut data Sample Registration System (SRS) Indonesia tahun 2014, Hipertensi dengan komplikasi $(5,3 \%)$ merupakan penyebab kematian nomor 5 (lima) pada semua umur. Sedangkan berdasarkan data International Health Metrics Monitoring and Evaluation (IHME) tahun 2017 di Indonesia, penyebab kematian pada peringkat pertama disebabkan oleh Stroke, diikuti dengan Penyakit Jantung Iskemik, Diabetes, Tuberkulosa, Sirosis, diare, PPOK, Alzheimer, Infeksi saluran napas bawah dan Gangguan neonatal serta kecelakaan lalu lintas.(Institute for Health Metrics and Evaluation, 2018; Usman et al., 2019)

Hipertensi dapat dicegah dengan mengendalikan perilaku berisiko seperti merokok, diet yang tidak sehat seperti kurang konsumsi sayur dan buah serta konsumsi gula, garam dan lemak berlebih, obesitas, kurang aktifitas fisik, konsumsi alkohol berlebihan dan stres. Data Riskesdas 2018 pada penduduk usia 15 tahun keatas didapatkan data faktor risiko seperti proporsi masyarakat yang kurang makan sayur dan buah sebesar $95,5 \%$, proporsi kurang aktifitas fisik $35,5 \%$, proporsi merokok 29,3\%, proporsi obesitas sentral 31\% dan proporsi obesitas umum 21,8\%. Data tersebut di atas menunjukkan peningkatan jika dibandingkan dengan data Riskesdas tahun 2013.(Badan Penelitian dan Pengembangan Kesehatan Kementerian Kesehatan RI, 2013)

Kelurahan Tomang merupakan wilayah yang terdapat di sekitar Fakultas Kedokteran Universitas Tarumanagara dan merupakan wilayah yang sering diajak kerjasama, seperti diperbantukan 
sebagai pasien simulasi. Berdasarkan hasil wawancara dan data dari kepala puskesmas Tomang didapatkan banyaknya warga kelurahan Tomang yang menderita Penyakit Tidak Menular (PTM.) Salah Satu penyakit PTM adalah hipertensi. Selain itu ditemukan pula kurangnya pengetahuan masyarakat tentang hipertensi cara pencegahannya serta kurangnya kesadaran pengaturan pola hidup yang sehat menjadi salah satu faktor resiko untuk terkena penyak hipertensi. Kelurahan Grogol juga merupakan salah satu kelurahan di Kecamatan Grogol Petamburan, Jakarta Barat. Kelurahan Grogol memiliki luas area 12,2 km2, yang terdiri atas 10 RW dan 114 RT. Didapatkan 6,943 KK dengan jumlah penduduk 20,214 jiwa.

\section{METODE PELAKSANAAN}

Persiapan kegiatan pengabdian diawali dengan rapat internal di Fakultas Kedokteran Universitas Tarumanagara untuk membahas ide kegiatan. Setelah disepakati bersama, tim pengusul membuat dan mengajukan proposal ke Direktorat Penelitian dan Pengabdian kepada Masyarakat (DPPM) UNTAR untuk mendapatkan hibah kegiatan.

Tim mengadakan kunjungan ke kantor Kelurahan Tomang dan Grogol untuk bertemu dengan Bapak dan Ibu Lurah dan para kader dari Kelurahan Tomang dan Grogol, Jakarta Barat guna menyampaikan ide kegitan, sekaligus memintakan ijin dan persetujuan dari Bapak dan Ibu Lurah. Setelah mendapat persetujuan, dilakukan rapat persiapan dengan tim kader dari kelurahan untuk pendataan warga dan penyebaran undangan.

Dilakukan rapat persiapan sebanyak tiga kali dengan tim dosen pelaksana, karyawan, dan mahasiswa FK UNTAR. Beberapa hari sebelum pelaksanaan, tim mengadakan rapat terakhir untuk membahas persiapan pelaksanaan, mempersiapkan peralatan (kuesioner, tensimeter, stetoskop) Pada hari pelaksanaan, disiapkan 1 buah meja yang digunakan sebagai meja registrasi bagi warga yang akan mengikuti kegiatan. Warga yang datang, dimintakan untuk menunjukkan KTP kepada mahasiswa yang bertugas di meja registrasi, selanjutnya dilakukan pendataan ulang terhadap warga.

\section{HASIL DAN PEMBAHASAN}

Kegiatan dilaksanakan pada hari Jumat, 4 Oktober 2019, dan 17-18 Oktober 2019 bertempat di Lantai 4, Gedung Fakultas Kedokteran Universitas Tarumanagara, Jakarta Barat. Kegiatan diawali dengan registrasi ulang para warga dengan menunjukkan KTP kepada mahasiswa yang bertugas di meja registrasi. Setelah registrasi, warga diberikan 1 berkas kuesioner, dan dipersilahkan masuk ke dalam ruang tunggu untuk dipandu pengisian kuesioner oleh tim pelaksana.

Pada kegiatan ini, jumlah warga yang berpartisipasi (Tabel 1) sebanyak 181 warga, 80 laki-laki $(44,2 \%)$ dan 101 perempuan (55,8\%). Sebanyak 50,8\% warga berusia antara 30-39 tahun. Berdasarkan tingkat pendidikan, 60,2\% warga memiliki tingkat pendidikan lanjutan atas (SMA/sederajat) dan 75,7\% warga sudah berkeluarga. Kegiatan PKM dapat dilihat pada Gambar 1.

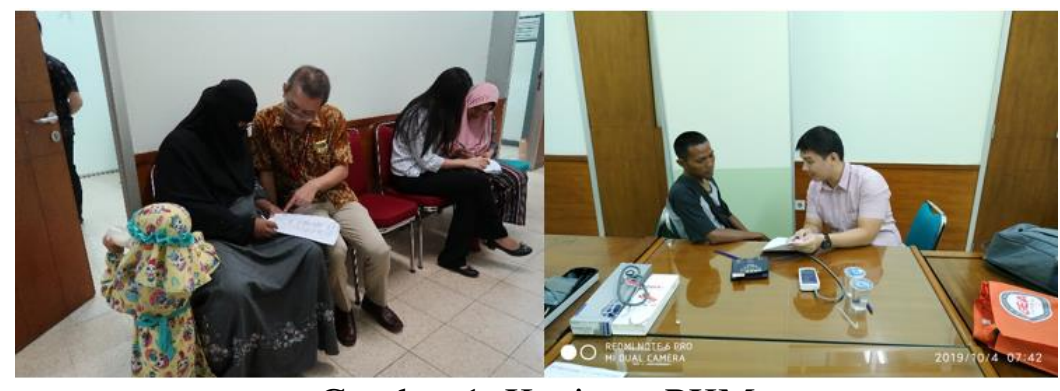

Gambar 1. Kegiatan PKM 
Berdasarkan besarnya pendapatan, didapatkan 40,3\% warga memiliki pendapatan antara Rp. 3,000,000,- sampai Rp. 4,000,000,- per bulan. Sebesar 46,4\% memiliki pendapatan dibawah upah minimum regional (< Rp. 3,000,000,-). Didapatkan 69,1\% warga merokok, 56,9\% warga melakukan olahraga rutin dan 55,8\% mengonsumsi kopi.

Tabel 1. Sebaran Karakteristik Warga

\begin{tabular}{llcc}
\hline No & Karakteristik (N=181) & & $\%$ \\
\hline 1. & Jenis Kelamin & & \\
& Laki-laki & 80 & $44,2 \%$ \\
& Perempuan & 101 & $55,8 \%$ \\
2. & Usia (tahun) & & \\
& 20-29 & 35 & $19,3 \%$ \\
& $30-39$ & 92 & $50,8 \%$ \\
& $\geq 40$ & 54 & $29,8 \%$ \\
3. & Tingkat Pendidikan & & \\
& Tidak sekolah & 3 & $1,7 \%$ \\
& SD & 14 & $7,7 \%$ \\
& SMP & 43 & $33,9 \%$ \\
& SMA/sederajat & 109 & $60,2 \%$ \\
Diploma & 5 & $2,8 \%$ \\
S1 & 7 & $3,9 \%$
\end{tabular}

4. Status Perkawinan

$\begin{array}{lcc}\text { Belum menikah } & 39 & 21,5 \% \\ \text { Menikah } & 137 & 75,7 \% \\ \text { Cerai } & 1 & 0,6 \% \\ \text { Duda/Janda } & 4 & 2,3 \%\end{array}$

5. Rata-rata Penghasilan per bulan

$\begin{array}{lcc}\text { Di bawah UMR } & 96 & 53,1 \% \\ \text { UMR } & 73 & 40,3 \% \\ \text { Di atas UMR } & 13 & 6,6 \%\end{array}$

6. Merokok

$\begin{array}{lcc}\text { Ya } & 56 & 30,9 \% \\ \text { Tidak } & 125 & 69,1 \%\end{array}$

7. Olahraga

$\begin{array}{lcc}\text { Ya } & 78 \quad 43,1 \% \\ & 103 & 56,9 \%\end{array}$

8. Minum Kopi

$\begin{array}{lcc}\text { Ya } & 101 & 55,8 \% \\ \text { Tidak } & 80 & 44,2 \%\end{array}$


Dari hasil pengukuran tekanan darah, didapatkan $88,4 \%$ warga tekanan darah nya tergolong normal. Rata-rata tekanan darah sistolik adalah $130,82 \mathrm{mmHg}$, dan tekanan darah diastolik 77.69 $\mathrm{mmHg}$ seperti yang dapat dilihat pada Tabel 2 .

Tabel 2. Sebaran Tekanan Darah Warga

\begin{tabular}{llcc}
\hline & Karakteristik & Mean;SD & \\
& Tekanan darah sistolik $(\mathrm{mmHg})$ & $130,82: 21,28$ & \\
& Tekanan darah diastolik $(\mathrm{mmHg})$ & 77,$69 ; 13,9$ & \\
\hline $\mathbf{1 .}$ & Hipertensi & & $\%$ \\
Ya & 21 & $11,6 \%$ \\
Tidak & 160 & $88,4 \%$ \\
\hline
\end{tabular}

Berdasarkan data Riset Kesehatan Dasar (Riskesdas) 2018, didapatkan prevalensi hipertensi di propinsi DKI Jakarta berdasarkan hasil pengukuran tekanan darah adalah 33,43\%.(Kementerian Kesehatan Republik Indonesia, 2018) Prevalensi hipertensi yang didapatkan pada kegiatan ini lebih rendah dibandingkan hasil Riskesdas 2018. Rendahnya nilai prevalensi yang didapatkan kemungkinan disebabkan karena sebagian besar warga yang datang adalah berjenis kelamin perempuan, dan tidak merokok.

Edukasi Senam Hipertensi diberikan melalui pemutaran video serta penjelasan oleh dr Novendy, MKK seperti yang dapat dilihat pada Gambar 2. Aktifitas fisik seperti senam hipertensi yang dilakukan secara teratur dapat menurunkan tekanan darah. Hermawan dalam penelitiannya mendapatkan terdapat perbedaan antara tekanan darah sistolik dan diastolik sebelum dan setelah senam.(Hernawan \& Nur Rosyid, 2017) Senam hipertensi merupakan salah satu bentuk aktifitas yang bertujuan untuk meningkatkan aliran darah dan masukan oksigen ke dalam otot jantung.

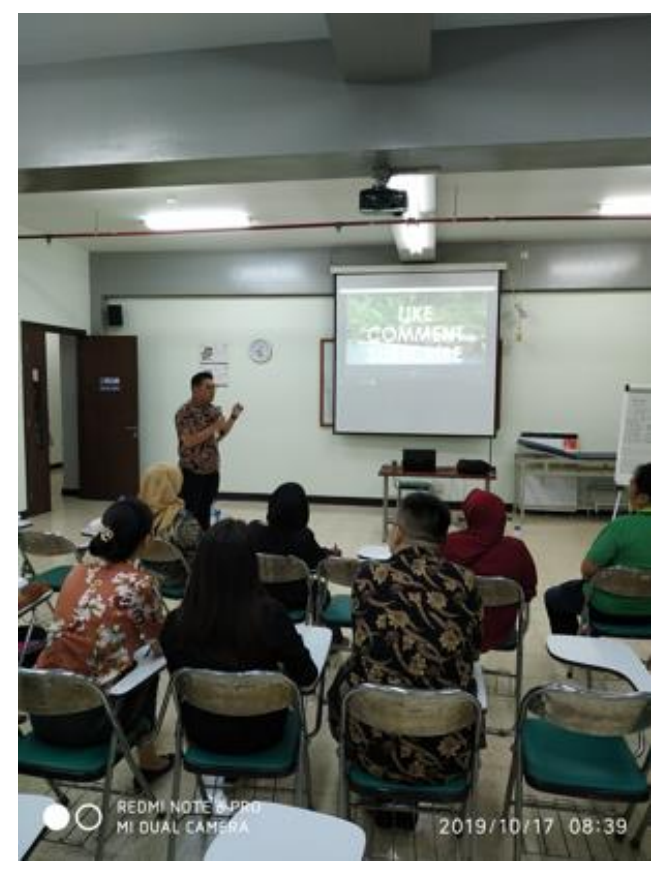

Gambar 2. Edukasi Senam Hipertensi 
Pelaksanaan kegiatan pengabdian berjalan sesuai dengan perencanaan, dan berjalan lancar dan tertib.

\section{KESIMPULAN}

Kegiatan pengabdian kepada masyarakat dengan topik "Pelatihan dan Edukasi Pola Hidup Sehat dalam Pencegahan "Hipertensi" Warga di sekitar Jakarta Barat melalui Senam dan Pemeriksaan Kadar Kolesterol Total" dilaksanakan dengan baik dan lancar pada tanggal 4 Oktober 2019 dan 17-18 Oktober 2019, dan dihadiri oleh 181 warga dari Kelurahan Tomang dan Grogol Jakarta Barat, 80 laki-laki $(44,2 \%)$ dan 101 perempuan $(55,8 \%)$. Hasil pengukuran tekanan darah, didapatkan $88,4 \%$ warga tekanan darahnya tergolong normal. Rata-rata tekanan darah sistolik adalah 130,82 $\mathrm{mmHg}$, dan tekanan darah diastolik $77.69 \mathrm{mmHg}$.

\section{Ucapan Terima Kasih (Acknowledgement)}

Kami mengucapkan terima kasih kepada Yayasan Tarumanagara, Bapak Rektor Universitas Tarumanagara, Dekan Fakultas Kedokteran Universitas Tarumanagara, dan Ketua Lembaga Penelitian dan Pengabdian kepada Masyarakat Universitas Tarumanagara serta mahasiswa Fakultas Kedokteran Universitas Tarumanagara atas dukungan yang diberikan mulai dari persiapan sampai penyelenggaraan kegiatan pengabdian ini. Kami juga mengucapkan terima kasih untuk dukungan, bantuan dan kerjasama dari Bapak Lurah dan Ibu-ibu kader/PKK Kelurahan Tomang Jakarta Barat dan terutama kepada seluruh warga masyarakat Kelurahan Tomang, Jakarta Barat yang sudah berpartisipasi dalam kegiatan ini.

\section{REFERENSI}

Badan Penelitian dan Pengembangan Kesehatan Kementerian Kesehatan RI. (2013). RISET KESEHATAN DASAR RISKESDAS 2013. Retrieved from http://www.depkes.go.id/resources/download/general/Hasil Riskesdas 2013.pdf

Hernawan, T., \& Nur Rosyid, F. (2017). Pengaruh senam hipertensi lansia terhadap penurunan tekanan darah lansia dengan hipertensi di panti wreda Darma Bhakti Kelurahan Pajang Surakarta. Kesehatan, 10(1), 26-31.

Hypertension. (n.d.). Retrieved December 6, 2019, from https://www.who.int/news-room/factsheets/detail/hypertension

Institute for Health Metrics and Evaluation. (2018). Findings from the Global Burden of Disease Study 2017. Retrieved from www.healthdata.org

Kementerian Kesehatan Republik Indonesia. (2018). Laporan Nasional Riskesdas 2018. Jakarta.

Pusat Data dan Informasi Kementerian Kesehatan Republik Indonesia. (1997). Infodatin Hipertensi. https://doi.org/10.1177/109019817400200403

Usman, Y., Iriawan, R. W., Rosita, T., Lusiana, M., Kosen, S., Kelly, M., ... Raoi, C. (2019). Indonesia's Sample Registration System in 2018: A work in progress. Journal of Population and Social Studies, 27(1), 39-52.

WHO. (2013). A global brief on hypertension | A global brief on Hyper tension. Retrieved from www.who.int 